\title{
Mechanizm wyboru deputatów z województwa mazowieckiego do Trybunału Koronnego w 1688 r. Przyczynek do badań układów klientalnych na Mazowszu w dobie panowania Jana III
}

W drugiej połowie XVII w. nieformalne układy polityczne (zwane w skrócie systemem fakcyjnym) zdominowały ustrój mieszany Rzeczypospolitej, wyrazem czego był wzrost siły nacisku przez grupy interesu na systemowe instytucje państwa. Proces ten nie ominął żadnego organu polsko-litewskiej państwowości, w tym najwyższego sądu szlacheckiego - Trybunału Koronnego, jak bowiem wskazują najnowsze wyniki badań, u schyłku XVII w. większość sejmików deputackich, które wybierały swych przedstawicieli do Trybunału, była zrywana ${ }^{1}$. Obstrukcja sejmików - zgodnie z logiką powyższego wywodu - powinna być skutkiem bieżącej walki politycznej, toczonej między różnymi grupami interesu (czyli fakcjami), które w składzie najwyższego szlacheckiego sądu chciały widzieć przychylne sobie osoby. Teza ta, z jednej strony oczywista, z drugiej kontrowersyjna, nie miała dotąd należytego poparcia w badaniach cząstkowych. $\mathrm{W}$ tej zależności należy upatrywać pierwszą przyczynę powstania niniejszego szkicu.

Zasadniczy powód do podjęcia badań nad problemem wyboru deputatów do Trybunału Koronnego z województwa mazowieckiego w 1688 r. dały wyniki kwerendy przeprowadzanej w tzw. Tekach Szczuki, obejmujących obszerny zbiór

${ }^{1}$ L.A. Wierzbicki, Wstep [w:] Deputaci Trybunatu Koronnego 1578-1794. Spis, cz. 3: 16611700, oprac. L.A. Wierzbicki, Warszawa 2017, s. 11-13; idem, Reasumpcje i limitacje Trybunatu Koronnego w latach 1660-1700, „Res Historica” 2017, z. 44, s. 63-74. Ostatnia z pozycji przedstawia aktualny stan badań nad Trybunałem Koronnym w drugiej połowie XVII w., co zwalnia mnie z obowiązku jego omówienia. Można tylko przypomnieć, że jedyną większą monografią poświęconą Trybunałowi jest rozprawa Waldemara Bednaruka, Trybunał Koronny. Szlachecki sąd najwyższy w latach 1578-1794, Lublin 2008. 
korespondencji, głównie listów kierowanych do Stanisława Antoniego Szczuki, regenta kancelarii koronnej i od 18 X $1688 \mathrm{r}$. referendarza koronnego ${ }^{2}$. Analiza tego materiału pozwoliła ukazać szereg pozasystemowych mechanizmów, od których zależało dojście do skutku sejmiku deputackiego Księstwa Mazowieckiego i wybór przychylnych deputatów danej fakcji. Eksplorowany zasób źródłowy obfituje także w cenne informacje faktograficzne, które pozwolą przybliżyć linię podziału stronnictw politycznych w województwie mazowieckim. Jest to o tyle istotne, że wewnętrzne układy w „powiedeńskim” okresie panowania Jana III (1684-1696) są wciąż niewystarczająco rozpoznane, zwłaszcza na poziomie lokalnym. Województwo mazowieckie należy natomiast postrzegać jako istotny element tej politycznej konstelacji, mimo że nie należało do najbogatszych i najbardziej wpływowych części Korony, ale centrum życia politycznego kraju znajdowało się na jego obszarze, w związku z czym wielu możnych musiało stworzyć tu swoje struktury, dzięki którym mogło mieć wpływ na ogólnopaństwowe decyzje. Celem studium jest zatem ukazanie mechanizmów wyboru deputatów do Trybunału Koronnego z województwa mazowieckiego w 1688 r., tj. wykazanie, na ile wybór oraz samo dojście sejmiku do skutku było efektem funkcjonowania miejscowych układów klientalnych. Problem jest o tyle ciekawy, że - zgodnie z tym, co zauważył Leszek A. Wierzbicki - we wrześniu 1688 r. zerwano największą liczbę sejmików deputackich w okresie rządów Jana III - świeckich sędziów miało być bowiem jedynie dziesięciu, co świadczy o istnym paraliżu mechanizmów ustrojowych ${ }^{3}$.

W dobie panowania Jana III, licząc od elekcji w maju 1674 r. do śmierci monarchy w czerwcu 1696 r., skład Trybunału Koronnego uległ pewnym modyfikacjom. W 1661 r. w Trybunale Koronnym mogło zasiadać 62 deputatów - 48 świeckich wybranych przez 27 sejmików deputackich (13 z prowincji wielkopolskiej i 14 z małopolskiej) oraz 14 duchownych desygnowanych przez 12 kapituł. W późniejszych latach liczbę deputatów z poszczególnych sejmików zwiększono tak, że po $1690 \mathrm{r}$. sędziów trybunalskich było nominalnie $67^{4}$.

Przez cały ten okres nie uległa zmianie liczba deputatów wybieranych przez województwo mazowieckie, składające się z dziesięciu partykularnych ziem z których każda posiadała swój szlachecki samorząd. Wybór sędziów do Trybunału na sejmiku generalnym Księstwa Mazowieckiego miał się odbywać na zasadzie alternaty ziem. Jak dowiodły jednak wiekowe, ale wciąż aktualne badania Józefa Andrzeja Gierowskiego, praktyka wyboru deputatów z województwa mazowieckiego na zasadzie alternaty nie miała wiele wspólnego z teorią. Od 1598 r. generał mazowiecki miał wybierać dwóch deputatów z dwóch partykularnych sejmików

${ }^{2}$ Archiwum Główne Akt Dawnych [dalej: AGAD], Archiwum Publiczne Potockich [dalej: APP], sygn. 163a, t. 15.

${ }^{3}$ L.A. Wierzbicki, Wstęp [w:] Deputaci Trybunatu..., s. 12.

${ }^{4}$ Ibidem, s. 8-11. 
według ustalonej kolejności, a właściwie według hierarchii ziem, począwszy od ziem czerskiej i warszawskiej, potem wiskiej i wyszogrodzkiej, zakroczymskiej i ciechanowskiej, łomżyńskiej i różańskiej, na liwskiej i nurskiej kończąc. Od początków XVII w. mazowieckie generały deputackie stały się jednak polem ustawicznych nadużyć: ,lekceważono alternatę ziem w obieraniu deputatów, wybierając ich z osób nieosiadłych po ziemiach; narzucono wybór groźbą i gwałtem; przeprowadzano go w tajemnicy przed większością szlachty; na niezwykłym miejscu; wreszcie rwano" - jak zanotował J.A. Gierowski ${ }^{5}$. Przyczyny zaistniałej sytuacji miały być wielorakie, począwszy od trudności ewidencji kandydatów na deputatów pod względem osiadłości, co ułatwiało zadanie dysponentom fakcji magnackich. Nie bez znaczenia miało być też miejsce odbywania sejmików, tj. Warszawa, która nie leżała w centrum województwa i przedstawiciele odległych ziem nie zawsze byli w stanie dotrzeć na posiedzenie generału deputackiego w odpowiedniej sile, co dawało np. uprzywilejowaną pozycję ziemi warszawskiej ${ }^{6}$. Ponadto Warszawa od schyłku XVI w. stanowiła centrum życia politycznego dualistycznej Rzeczypospolitej, wskutek czego przebywało w jej granicach wielu możnych decydentów, którzy nie mogli nie wykorzystać nadarzających się okazji, aby wybór przedstawicieli do najwyższego sądu szlacheckiego spróbować uzależnić od własnych potrzeb. Widać zatem, że zależność sejmiku deputackiego Księstwa Mazowieckiego od fakcji magnackich zaczęła się kształtować jeszcze w okresie, w którym tzw. system fakcyjny nie odgrywał jeszcze tak doniosłej roli, tj. w pierwszej połowie XVII w. ${ }^{7}$

$\mathrm{Na}$ okres panowania Jana III przypadły 22 kadencje posiedzeń Trybunału. Opierając się na badaniach L.A. Wierzbickiego, można stwierdzić, że w tym czasie z sejmiku generalnego mazowieckiego deputatów wybrano na pewno 15 razy - z tym że z trzech kadencji znamy tylko po jednym z dwóch deputatów (dla kadencji: 1682/1683, 1683/1684 i 1694/1695), a z kadencji 1678/1679 nie ustalono personaliów żadnego. W dobie panowania Jana III generał deputacki zerwano przynajmniej pięć razy (w latach: 1684, 1687 i 1690-1692). Na temat

5 J.A. Gierowski, Sejmik generalny Księstwa Mazowieckiego na tle ustroju sejmikowego Mazowsza, Wrocław 1948, s. 150-151.

${ }^{6}$ Ibidem, s. 151-152; J. Choińska-Mika, Sejmiki mazowieckie $w$ dobie Wazów, Warszawa 1998, s. 33-34. O Warszawie jako ośrodku dyspozycji politycznej w dobie Wazów zob. A. Pieńkowska, M.A. Pieńkowski, Sejmiki mazowieckie wobec problemów wewnętrznych Rzeczypospolitej w latach 1661-1665, Oświęcim 2015, s. 15-34.

7 Warto dodać, że w tym okresie mechanizmy protekcyjne - przede wszystkim te wypracowane przez biskupów płockich - odgrywały niemałą rolę przy wyborach urzędników innych sądów, a mianowicie ziemskich; zob. A. Moniuszko, Mazowieckie sady ziemskie (1588-1648). Organizacja-funkcjonowanie - postępowanie, Warszawa 2013, s. 131-140; K. Wiśniewski, Wpływ polityczny Stanistawa Eubieńskiego, biskupa płockiego w latach 1627-1640, na szlachtę mazowiecka i podlaską: próba rekonstrukcji zaplecza politycznego, „Rocznik Mazowiecki” 2002, t. 14, s. 27-49. 
kadencji 1674/1675 i 1695/1696 nie dysponujemy żadnymi danymi ${ }^{8}$. Przyglądając się parom mazowieckich deputatów w kolejnych latach panowania Jana III, nie można stwierdzić, by generał województwa szczególnie respektował kwestię alternaty ziem - a to potwierdza wyżej zamieszczoną uwagę J.A. Gierowskiego 9

W okresie poprzedzającym tytułową kadencję Trybunału, a więc 1688/1689, sejmik deputacki Księstwa Mazowieckiego był zerwany dwa razy - i to dopiero w „powiedeńskiej” dobie panowania Jana III, a więc wówczas, gdy wzmogła się działalność opozycyjna Sapiehów w Wielkim Księstwie Litewskim, wspierana przez część elit Korony ${ }^{10}$. Pierwszy raz za Jana III generał deputacki województwa mazowieckiego zerwano w 1684 r. - włącznie z sejmikiem sąsiedniego województwa płockiego w Raciążu. Opat paradyski Kazimierz Szczuka pisał o tym następująco: „sejmiki electionis deputatów w Warszawie, w Raciążu rozerwane na marszałku, albowiem konkurentów gwałt - jeden drugiemu ustąpić nie chciał"11. Według opata sejmiki deputackie dwóch województw historycznego Mazowsza zerwano na etapie wyboru marszałka, ponieważ żaden z kandydatów na dyrektora nie chciał ustąpić. Generał deputacki Księstwa Mazowieckiego ponownie zerwano tuż przed tytułową kadencją, a więc w 1687 r., choć w tym przypadku powody obstrukcji sejmikowej pozostają nieznane ${ }^{12}$. Dowodów na to, że w obu przypadkach o rozejściu się generału deputackiego decydowała wzmożona walka polityczna poszczególnych koterii sympatyzujących z dworem królewskim tudzież z opozycją, nie ma. Jednak z korespondencji kręgu informatorów Stanisława A. Szczuki wynika, że zarówno nadawcy, jak i adresat byli żywo zainteresowani kwestią sprawnego odbywania sejmików w województwie mazowieckim. Krąg Szczuki stanowił natomiast zaplecze polityczne dworu Jana III - m.in. właśnie na Mazowszu.

${ }^{8}$ Deputaci Trybunatu..., s. 105-250; L.A. Wierzbicki, The Masovian Voivodship's deputy sejmiks and their deputies to the Crown Tribunal in the years 1660-1700, „Wschodni Rocznik Humanistyczny" 2019, t. 16, z. 2, s. 133-141.

9 Por. L.A. Wierzbicki, The Masovian Voivodship’s deputy sejmiks..., s. 137.

${ }_{10}$ Zob. np.: A. Rachuba, Hegemonia Sapiehów na Litwie jako przejaw skrajnej dominacji magnaterii w życiu kraju [w:] J. Urwanowicz, E. Dubas-Urwanowicz, P. Guzowski (red.), Władza i prestiz. Magnateria Rzeczypospolitej w XVI-XVIII wieku, Białystok 2003, s. 217-229; P.P. Romaniuk, Instytucjonalne podstawy hegemonii Sapiehów w Wielkim Księstwie Litewskim w drugiej połowie XVII w. [w:] U. Kosińska, D. Dukwicz, A. Danilczyk (red.), W cieniu wojen i rozbiorów. Studia $z$ dziejów Rzeczypospolitej XVIII i początków XIX wieku, Warszawa 2014, s. 29-37; M. Sawicki, Dom sapieżyński 1666-1685. Droga do hegemonii w Wielkim Księstwie Litewskim, Opole 2016; R. Kołodziej, Stronnictwo Sapiehów a funkcjonowanie sejmu w drugiej części panowania Jana III Sobieskiego (1685-1696) [w:] T. Ciesielski, M. Sawicki (red.), Wielkie rody dawnej Rzeczypospolitej XVI-XIX wieku, t. 1: Sapiehowie, Opole 2018, s. 105-119.

${ }^{11}$ AGAD, APP, sygn. 163a, t. 10, s. 676, K. Szczuka do S.A. Szczuki, Warszawa, 17 IX 1684; L.A. Wierzbicki, The Masovian Voivodship's deputy sejmiks..., s. 136.

${ }^{12}$ AGAD, APP, sygn. 163a, t. 14, s. 947, Jan Zakrzewski do S.A. Szczuki, Warszawa 17 IX 1687. 
Stanisław A. Szczuka bardzo szybko, po wstąpieniu na służbę królewską w 1675 r. w charakterze sekretarza (za protekcją krewnego Kazimierza), zdobył uznanie i zaufanie Jana III - wskutek wysokiej kultury politycznej i poziomu wykształcenia. W 1682 r. otrzymał urząd podczaszego wiskiego, co - jak przypuszczają historycy - wiązało się z jego zamiarami stworzenia w ziemi wiskiej rezydencji i ośrodka dóbr dziedzicznych. Sam, w przeciwieństwie do krewnych Kazimierza i stolnika wiskiego oraz oficera zaciągu niemieckiego Wacława, pochodził z Wielkiego Księstwa Litewskiego, a nie z ziemi wiskiej. W 1684 r. został regentem kancelarii koronnej (czy była to kancelaria większa, czy mniejsza, dotąd nie ustalono). Stanowisko to dawało Szczuce spory zakres władzy. Kontrolował pisma wychodzące z kancelarii pod względem ich zgodności z obowiązującym prawem, ale miał też wpływ na całą pracę kancelarii, w tym redakcję wystawianych pism i uwierzytelnianie ich właściwą pieczęcią. Dla starających się o godności były to sprawy pierwszorzędne. Formalnie za całość prac odpowiadał któryś z koronnych pięczętarzy, ale w opinii wielu to regent był faktycznym kierownikiem kancelarii i dlatego o jego względy zabiegano. Szczuka dysponował zatem realnymi możliwościami protekcyjnymi, mogąc kaptować poszczególnych petentów do godności i beneficjów na potrzeby bieżącej polityki królewskiej. Z tych właśnie powodów podczaszy wiski w okresie rejencji stał się jednym z głównych filarów partii dworskiej i kreatorów jej polityki w „powiedeńskim” okresie panowania Jana III. Zakres jego wpływów obejmował Mazowsze, zwłaszcza ziemię wiską i po części czerską (od 1683 r. był starostą wareckim), ale także województwo lubelskie i niektóre powiaty rdzennej Litwy. Od 1687 r. był grodowym starostą lubelskim (starostwo objął w styczniu 1688 r.), co skutkowało wzrostem jego zainteresowań sytuacją polityczną w Lubelskiem, w tym przebiegiem sesji Trybunału Koronnego ${ }^{13}$. Z dotychczas przytoczonych faktów wynika, że Szczuka miał atrybuty, ale i powody, by nadzorować wybór deputatów z województwa mazowieckiego w $1688 \mathrm{r}$.

Generał mazowiecki, który miał wybrać deputatów do kadencji Trybunału 1688/1689, odbył się w środę 15 IX 1688 - zatem dwa dni po terminie przewidzianym prawem z 1578 r. Sejmiki deputackie miały odbywać się przecież w poniedziałek po Narodzeniu NP. Marii, czyli między 9 a 15 IX (większość sejmików w 1688 r. obradowała właśnie 13 IX) ${ }^{14}$. W tym czasie armie Rzeczypospolitej prowadziły kampanię kamieniecką przeciw Porcie Ottomańskiej, zakończoną 29 IX

${ }^{13}$ Na podstawie: A. Michałowska, Stanisław Antoni Szczuka - poczatki kariery patrona, „Kwartalnik Historyczny” 1995, t. 102, z. 3-4, s. 61-90; T. Zielińska, Stanisław Antoni Szczuka jako referendarz koronny w latach 1688-1699, „Kwartalnik Historyczny” 2004, t. 111, z. 3, s. 5-22.

14 J.A. Gierowski, Sejmik generalny Księstwa Mazowieckiego..., s. 150; Deputaci Trybunału..., s. 201. Uchwała sejmikowa generału z 1688 r. prawdopodobnie się nie zachowała. Brak jej wśród XIX-wiecznych wypisów z ksiąg grodzkich województwa mazowieckiego; zob. Biblioteka Naukowa Polskiej Akademii Umiejętności i Polskiej Akademii Nauk w Krakowie [dalej: BN PAU/PAN], rkps 8334 . 
bez osiągnięcia większych korzyści. Król przebywał wówczas w Złoczowie, zaś S.A. Szczuka jeszcze 13 IX przebywał w obozie wojska, skąd informował władcę m.in. o dalszych planach dowództwa polsko-litewskiego ${ }^{15}$. Wskutek nieobecności regenta Szczuki bezpośrednie baczenie na przebieg obrad mazowieckiego sejmiku deputackiego musieli mieć jego polityczni współpracownicy, począwszy od krewnego, opata paradyskiego. Zresztą to jego list z 15 IX z Warszawy jest głównym źródłem wiedzy na temat przebiegu mazowieckiego generału deputackiego. K. Szczuka pisał: „za staraniem jmp. referendarza koronnego, który rano sejmik electionis na deputaty convocationis senatoribus przypuścił, szczęśliwie mamy obranych deputatów: z Łomży jmp. Moczarskiego, z Różana jmp. Petrykowskiego, stolnika różańskiego. Gdyby ten zjazd przed południem [...] nie odprawił się, spadać się mógł. Zagaił go jmp. wiski, mianowawszy dyrektorem jmp. podkomorzego łomżyńskiego i ten szczęśliwie gospodarował"16.

List ten ujawnia wiele mechanizmów: po pierwsze, przygotowanie sejmiku wziął na siebie referendarz koronny i starosta warszawski Jan Dobrogost Krasiński - i to jego pracy K. Szczuka przypisuje „szczęśliwe” obranie deputatów. Po drugie, same obrady zainicjował kasztelan wiski Florian Drozdowski, który doprowadził do szybkiego wyboru marszałka sejmikowego - podkomorzego łomżyńskiego Zygmunta Zbierzchowskiego, ten zaś skutecznie kierował obradami, dzięki czemu jeszcze przed południem wybrano dwóch deputatów z alternaty łomżyńskiej i różańskiej: Wojciecha Kazimierza Moczarskiego, stolnika i podstarościego łomżyńskiego, oraz Hieronima Petrykowskiego, stolnika różańskiego. Szybkość w działaniu zapobiegła zerwaniu zjazdu, opat paradyski twierdzi bowiem, że przedłużenie sejmiku do tego by właśnie doprowadziło. Opis Szczuki przedstawia nam zatem schemat działania lokalnej elity w kwestii przeprowadzania wyboru sędziów trybunalskich, ale też sugeruje istnienie czynników, które mogły prowadzić do zerwania sejmiku.

Istotną rolę w organizacji sejmiku deputackiego w $1688 \mathrm{r}$. odegrał Jan D. Krasiński, który - jak wynika z relacji posła angielskiego Karola II do Jana III, Lawrence'a Hyde'a - oddziaływał na przebieg tego rodzaju zjazdu już w 1676 r. ${ }^{17}$

${ }^{15}$ AGAD, APP, sygn. 47, t. 1, s. 608-614, S.A. Szczuka do Jana III, obóz pod Torskiem, 13 IX 1688; M. Wagner, Kampania kamieniecka 1688 roku [w:] D. Milewski (red.), Jarzmo Ligi Świętej? - Jan III Sobieski i Rzeczpospolita w latach 1684-1696, Warszawa 2017, s. 189-212 (zwłaszcza s. 205-206).

${ }^{16}$ AGAD, APP, sygn. 163a, t. 15, s. 769-771, K. Szczuka do S.A. Szczuki, Warszawa, 15 IX 1688.

${ }^{17}$ W trakcie pobytu Hyde'a w Warszawie, najpierw pod datą 14 IX 1676 odnotowano o wyborach sędziów do Trybunału: „that it was a meeting of the gentleman of the province of Mazovia, in order to send some persons of their choosing to attend at Lublin, at a court of judicature that was to be kept there, for the trial of extraordinary causes and particularly relating to the gentleman of Poland". Następnie, dzień później, informowano o przybyciu Krasińskiego, który swoją zwłokę 
W 1688 r. mijało 20 lat, odkąd sprawował godności referendarza koronnego i starosty grodowego w Warszawie. Pochodził z rodziny o tradycyjnych, silnych wpływach politycznych na Mazowszu, wskutek czego wielokrotnie pełnił powinności posła na sejmy czy marszałka mazowieckich sejmików partykularnych. Był ponadto zięciem (od 1680 r.) wojewody ruskiego i hetmana wielkiego koronnego Stanisława Jana Jabłonowskiego, mogąc liczyć na jego poparcie. W kwestii stosunku referendarza do dworu królewskiego Jana III w omawianym okresie w literaturze występują rozbieżności, zaliczany jest on bowiem do grona zwolenników, jak również do opozycjonistów. Dowodem na działalność antykrólewską Krasińskiego miał być jego diariusz działań wojennych 1683 r., uznawany za pismo polityczne i zawierający krytykę monarchy ${ }^{18}$. Tę publicystykę należy jednak potraktować jako przejaw rozgoryczenia wskutek nieprzyznania referendarzowi w 1683 r. urzędu wojewody pomorskiego, o który zabiegał. Dalszy bieg wydarzeń dowodzi, że Krasiński przeszedł szybko nad swym niepowodzeniem do porządku dziennego i chcąc uzyskać inną godność senatorską, podjął współpracę z partią dworską. Godził się przy tym na wiodącą rolę S.A. Szczuki, choć sam przewyższał go urzędem czy lepszym sytuowaniem rodu ${ }^{19}$. Wymowny jest bowiem fakt, że regent koronny objął urząd awansowanego Krasińskiego.

Zaangażowanie referendarza w kwestię zorganizowania obrad generału deputackiego we wrześniu 1688 r. dość szybko zaprocentowało. K. Szczuka, informując kuzyna Stanisława o zerwaniu kilku sejmików deputackich (rawskiego, łęczyckiego, piotrowskiego i lubelskiego), wspomniał, że wojewoda płocki Samuel Prażmowski „,ciężko chory na Pradze, była gorączka i róża przy tym, która do głowy poszedłszy, gardło ex asper eiunt, tak że jeść chory od kilkunastu dni nie chce

w powitaniu posła usprawiedliwiał załatwianiem interesów ze szlachtą mazowiecką na odbytym generale mazowieckim: „About ten the Referendarius came to me, having sent just a minute before: he excused his having been three or four days in town before he came hither, but that he had so much business with the gentleman of the country, which he said always in drinking"; Diary of the Honourable Laurence Hyde, constaining the particular occurences during his embassy to John Sobieski, King of Poland, in 1676 [w:] The correspondence of Henry Hyde, Earl of Clarendon, and on his brother Laurence Hyde, earl of Rochester, t. 1, oprac. S. Weller Singer, London 1828, s. 591, 592.

${ }^{18}$ [J.D. Krasiński], Relacja wyprawy wiedeńskiej 1683 roku, oprac. O. Laskowski, „Przegląd Historyczno-Wojskowy” 1930, t. 2, z. 1, s. 156-169; A. Czarniecka, Nikt nie stucha mnie za życia... Jan III Sobieski w walce z opozycyjna propaganda (1684-1696), Warszawa 2009, s. 110-114.

19 Podstawowe informacje o Krasińskim (z zaliczeniem go do grona zwolenników Jana III) zawiera jego biogram - który niewątpliwie w wielu miejscach wymaga aktualizacji; zob. A. Przyboś, Krasiński Jan Dobrogost [w:] Polski Stownik Biograficzny [dalej: PSB], t. 15, 1970, s. 180-182. O roli Krasińskich na Mazowszu jako najpotężniejszego rodu w tym regionie do końca XVII w., zob. J. Dzięgielewski, Mazowszanie w życiu publicznym Rzeczypospolitej od rokoszu Zebrzydowskiego do abdykacji Jana Kazimierza [w:] J. Dzięgielewski (red.), Mazowsze w procesach integracyjnych i dezintegracyjnych w Rzeczypospolitej XVI-XVII wieku. Studia i szkice, Warszawa 2010, s. 101 . 
i stąd osłabiał na siłach [...] i że ma 69 lat; a. 1619 natus in augusto"20. Kilka dni później ten sam Szczuka, gdy Prażmowski już dokonał żywota, wyraził opinię ,że śmierć wojewody płockiego otwiera jmp. referendarzowi koronnemu portam łaski pańskiej"21. I rzeczywiście tak było, choć powierzenie Krasińskiemu urzędu wojewody płockiego poprzedziła jeszcze protekcja teścia Jabłonowskiego, oczywiście za pośrednictwem regenta Szczuki ${ }^{22}$. Tym sposobem postawa Krasińskiego w $1688 \mathrm{r}$. pomogła mu zdobyć krzesło w senacie, a także ściślej związać się z prodworskimi nieformalnymi strukturami na Mazowszu - w grudniu miał bowiem przygotować sejmik przedsejmowy ziemi warszawskiej, o czym zostanie jeszcze powiedziane.

Kolejne osoby, które odegrały swoją rolę w organizacji generału deputackiego mazowieckiego w 1688 r., to F. Drozdowski i Z. Zbierzchowski. Pierwszy był formalnie najwyższym w hierarchii urzędnikiem ziemi wiskiej, ale politycznie zależał od regenta Szczuki, ,zaledwie” wiskiego podczaszego. W 1686 r. sam został wybrany deputatem do Trybunału, o czym zawiadomił Szczukę listownie, składając przy tym wymowne zobowiązanie: „desor WMM Panu na którym [Trybunale] jeśli jakieś occurent okazyje do przysługi JKM PMM moją szczerą i życzliwą ofiaruję aplikacyją [...]”. Ponadto wyraził gotowość bycia na Trybunale patronem i promotorem interesów samego Szczuki ${ }^{23}$. Sformułowania zawarte w tym liście trudno klasyfikować wyłącznie jako kurtuazję. Stanowią one po prostu dowód na zależność Drozdowskiego od regenta koronnego, ale i na jego prodworską orientację. W związku z tym wydaje się, że Drozdowski, jako senator inicjujący obrady generału w 1688 r. i osoba odpowiedzialna za wybór przychylnego swojemu środowisku marszałka, był ważnym ogniwem mazowieckich układów klientalnych. W tej materii potrzeba jednak dalszych badań.

Dyrektorem koła sejmikowego we wrześniu 1688 r. został Z. Zbierzchowski, weteran licznych wojen i wieloletni oficer kawalerii, wsławiony przede wszystkim w kampanii wiedeńskiej wykonaniem próbnej szarży na tureckie namioty. Od 1683 r. dowodził komputową chorągwią husarską królewicza Aleksandra, co wiązało go z Domem Sobieskich. Z wojska wystąpił po kampanii kamienieckiej 1687 r., skupiając się odtąd na działalności publicznej. Miał już zresztą doświadczenie w tej materii, m.in. jako marszałek sejmiku łomżyńskiego w 1673 r. Będąc dawnym dowódcą wojskowym, i to jeszcze z tak długim stażem, renomą i pozycją

${ }^{20}$ AGAD, APP, sygn. 163a, t. 15, s. 773-774, K. Szczuka do S.A. Szczuki, Warszawa, 22 IX 1688. Data narodzin oraz okoliczności śmierci Prażmowskiego pozostawały dotąd nieznane; zob. A. Przyboś, Prażmowski Samuel Jerzy [w:] PSB, t. 28, 1984, s. 380-381.

${ }^{21}$ AGAD, APP, sygn. 163a, t. 9, s. 213, K. Szczuka do S.A. Szczuki, Warszawa, 29 IX 1688.

22 AGAD, APP, sygn. 163a, t. 15, s. 827, S.J. Jabłonowski do S.A. Szczuki, Lwów, 4 X 1688. Hetman wielki zaznaczył tu, że „nie śmie” prosić bezpośrednio króla o województwo płockie dla zięcia, ale z protekcją w tej materii zwróci się do królowej Marii Kazimiery.

${ }^{23}$ AGAD, APP, sygn. 163a, t. 13, s. 349-350, F. Drozdowski do S.A. Szczuki, Warszawa, 10 IX 1686. 
społeczną (najwyższy dostojnik w ziemi łomżyńskiej jako podkomorzy), musiał dysponować umiejętnością sprawnego zarządzania grupą ludzi, dlatego jego doświadczenie wyniesione z obozów wojskowych oraz z pól bitewnych mogło okazać się przydatne w dyscyplinowaniu zastępów szlachty na sejmiku - w końcu, zdaniem K. Szczuki, w 1688 r. ,gospodarował szczęśliwie”24. Zbierzchowski nie po raz ostatni zresztą przewodził mazowieckiemu generałowi. Za jego laski we wrześniu 1690 r. odbył się z pomyślnym skutkiem sejmik generalny, na którym z województwa mazowieckiego wybrano komisarzy do trybunału skarbowego we Lwowie ${ }^{25}$.

Mniej na ten moment można powiedzieć o politycznych powiązaniach deputatów wybranych na Trybunał, choć jeden z nich - H. Petrykowski - jeszcze jako oficer zaciągu niemieckiego w wojsku koronnym był w 1673 r. posłem na sejm od armii skonfederowanej w Szczebrzeszynie. Ówczesna delegacja wojskowa reprezentowała interesy środowiska politycznego Sobieskiego, tym sposobem Petrykowski wykazał pewne związki polityczne z ówczesnym marszałkiem i hetmanem wielkim. Fakt ten nie jest jednak wystarczający, by scharakteryzować preferencje stolnika różańskiego w $1688 \mathrm{r}^{26}$ Niewątpliwie jednak deputaci wybrani przez sejmik generalny musieli odpowiadać opcji politycznej, która przejęła kontrolę nad tym zjazdem. W efekcie środowisko polityczne S.A. Szczuki powinno poczytać sobie za sukces to, że Petrykowski został wybrany marszałkiem Trybunału w kadencji 1688/1689.

Szczególnie zadowolony był wówczas biskup krakowski Jan Małachowski, osoba dość blisko związana z Janem III. Pisał on w październiku 1688 r. do Szczuki w kwestiach wakansów, w tym z obietnicą „gorącej supliki” do króla o powierzenie adresatowi listu - po awansie Krasińskiego na województwo płockie - referendarii koronnej. Przede wszystkim jednak informował, iż ma świeżą wiadomość z Piotrkowa: ,że tam nostra Regnat Masovia w osobie jmp. Petrykowskiego stolnika różańskiego, który angariatus supposuit humeros lasce i dyrekcyjej tam tego Trybunału. Już tedy non despero, że faventibus astris Księstwa Mazowieckiego"27.

${ }^{24}$ M. Wagner, Zapomniany bohater bitwy wiedeńskiej. Zygmunt Zbierzchowski (około 16351691) - porucznik husarski [w:] A. Smoliński (red.), Do szarży marsz, marsz... Studia z dziejów kawalerii, t. 4, Toruń 2013, s. 63-79. Zbierzchowski działał już na korzyść dworu jako poseł wojskowy na sejm 1683 r., zob. Z. Hundert, Poselstwo od wojska koronnego na sejm warszawski 1683 roku jako przykład patronatu wojskowego Jana III, „Roczniki Humanistyczne” 2018, t. 66, z. 2, s. 47.

${ }_{25}$ BN PAU/PAN, rkps 8334, k. 251-252v, laudum generału mazowieckiego, Warszawa, 12 IX 1690.

${ }^{26}$ Z. Hundert, Między buława a tronem. Wojsko koronne $w$ walce stronnictwa malkontentów z ugrupowaniem dworskim w latach 1669-1673, Oświęcim 2014, s. 191, 343-344, 352; por. J. Dziegięlewski, Petrykowski Hieronim [w:] PSB, t. 25, 1980, s. 709-710.

${ }^{27}$ AGAD, APP, sygn. 163a, t. 15, s. 1065-1066, J. Małachowski do S.A. Szczuki, Kielce, 11 X 1688. O regaliźmie Małachowskiego zob. J. Stolicki, Postawa polityczna biskupa krakowskiego Jana Małachowskiego w świetle jego korespondencji [w:] P. Borek, M. Olma (red.), Epistologra- 
Jak widać, Małachowski, choć niezwiązany w większym stopniu z Mazowszem (przez urząd, aktywność polityczną czy pochodzenie i kompleks dóbr) utożsamiał się z nim, z satysfakcją donosząc, że marszałkiem Trybunału został Petrykowski. Dyrektor wyznaczony spośród deputatów, wybranych uprzednio na sejmiku opanowanym przez prokrólewskie siły, stanowił niewątpliwie o sukcesie regalistów na Mazowszu - i stąd radość Małachowskiego. Sukces ten nie prezentuje się jednak okazale, gdy weźmiemy pod uwagę, że w 1688 r. liczba świeckich deputatów w Trybunale była najmniejsza w czasie całego panowania Jana III ${ }^{28}$.

W kontekście organizacji generału deputackiego w 1688 r. nie pada informacja, która siła polityczna stanowiła zagrożenie dla pomyślnego przebiegu zjazdu czy - szerzej rzecz ujmując - dla działalności partii dworskiej w województwie mazowieckim. Tego dowiemy się dopiero z listu nowego wojewody płockiego J.D. Krasińskiego do nowego referendarza koronnego S.A. Szczuki, gdy przygotowywano przedsejmowy sejmik ziemi warszawskiej w grudniu $1688 \mathrm{r}$. Wojewoda pisał: „sejmik warszawski ad nutum jmp. całym sporządzam sercem, i już z obywatelów miesza tu mieć żadnego sprzecznego p. marszałek wielki a bardziej p. podskarbi litewski; [...] z panem Rostworowskim dla mnie najciężsi i chcą mi koniecznie on rozerwać a go z niemi przez przyjaciół qualiter" ${ }^{29}$. Ten list również dostarcza nam cennych informacji. Krasiński przygotowywał sejmik ziemi warszawskiej pod egidą S.A. Szczuki, zaznaczając, że na pewno będą chcieli go zerwać marszałek wielki koronny Stanisław Herakliusz Lubomirski, a przede wszystkim podskarbi wielki litewski Benedykt Pawel Sapieha, a więc faktyczni przywódcy koronnej i litewskiej opozycji w $1688 \mathrm{r} .{ }^{30}$ Krasiński uznał ich, razem z chorążym liwskim Jackiem Rostworowskim, za najtrudniejszych rywali. Zresztą o tym, że Rostworowski (z „przyjaciółmi”) będzie dążył do zerwania sejmiku przedsejmowego ziemi warszawskiej w pierwszym terminie, informował Szczukę inny przedstawiciel lokalnych elit, blisko związany z Domem Sobieskich (jako marszałek dworu królowej) - starosta różański Franciszek Wessel, w latach 1691-1696 wojewoda mazowiecki ${ }^{31}$. Rostworowski bez wątpienia zaliczał się do

fia w dawnej Rzeczypospolitej, t. 4: Stulecia XVI-XIX. Perspektywa historyczna i językowa, Kraków 2013, s. 147-148.

${ }^{28}$ Na pierwszej sesji, gdy wybrano marszałka, świeckich deputatów znajdowało się zaledwie sześciu (przy dwunastu duchownych); zob. AGAD, APP, sygn. 163a, t. 15, s. 93, Regestr ichmościów deputatów Trybunału piotrkowskiego na pierwszej sesjej przytomnych die 11 octobris 1688.

${ }^{29}$ AGAD, APP, sygn. 163a, t. 15, s. 987, J.D. Krasiński do S.A. Szczuki, Warszawa, 8 XII 1688.

${ }^{30}$ J. Stolicki, Konflikt Jana III z opozycja magnacka w latach 1688-1689. Czy Sobieski mógt i powinien rozprawić się z opozycją? [w:] D. Milewski (red.), Jarzmo Ligi Świętej?..., s. 65.

${ }^{31}$ AGAD, APP, sygn. 163a, t. 15, s. 1435-1438, F. Wessel do S.A. Szczuki, Warszawa, 1 XI 1688. Warto dodać, że Wessel był doświadczonym parlamentarzystą. Nim uzyskał godność senatorską w 1691 r., posłował z sejmiku różańskiego na wszystkie sejmy w czasach Jana III (w latach 1676-1690). Jako wojewoda był na pewno na sejmach dwa razy (1693 i 1695); zob. R. Kołodziej, 
sług marszałka wielkiego Lubomirskiego. Interesy swojego patrona reprezentował już w 1683 r. w charakterze posła ziemi warszawskiej, jak pisał bowiem pisał pod koniec 1682 r. K. Szczuka: ,sejmik warszawski ex voto publico stanął [...]. Jmp. marszałek koron. był na tym zjeździe i otrzymał od braciej, że krewny i domowy jmści, to jest jmp. Rostworowski, chorąży liwski i jmp. [Jan Kazimierz - Z.H.] Szymanowski, podstoli warszawski stanęli posłami”32. Ponadto, jako plenipotent S.H. Lubomirskiego, chorąży liwski odbierał środki cesarskie przeznaczone na regiment pieszy pryncypała ${ }^{33}$. Widać zatem, że w ziemi warszawskiej - ale i w całym województwie głównym rywalem środowiska dworskiego był układ stworzony przez Lubomirskiego i Sapiehów. O ile nie zdołał on zdobyć wpływu na generał deputacki we wrześniu, o tyle sejmik przedsejmowy ziemi warszawskiej w grudniu 1688 r. został pod jego naciskiem zerwany ${ }^{34}$.

Sytuacja polityczna Rzeczypospolitej w 1688 r. - nie licząc kwestii wojny tureckiej - była niezwykle napięta, a dwór jeszcze wiosną podjął przygotowania do rozprawienia się z Sapiehami i ich sojusznikami ${ }^{35}$. Walka fakcyjna toczyła się też na poziomie lokalnym, co widać wyraźnie w procesie przygotowań tytułowego generału deputackiego czy wspominanego sejmiku przedsejmowego ziemi warszawskiej. W regionie jednym z głównych przeciwników dworu, jak wskazywał Krasiński, był S.H. Lubomirski, który od czasu objęcia godności marszałka wielkiego koronnego aktywność polityczną (ale nie tylko) przeniósł na Mazowsze. Obsadzając struktury urzędu marszałkowskiego miejscową szlachtą spacyfikował tradycyjne antymarszałkowskie nastroje, zwłaszcza w ziemi warszawskiej, zyskując - chyba jako pierwszy marszałek - dużą popularność na Mazowszu ${ }^{36}$. Zapewne przy jego pomocy swoje struktury w regionie tworzył główny w tym czasie współpracownik polityczny Lubomirskiego - B.P. Sapieha, faktyczny przywódca stronnictwa sapieżyńskiego (formalnym był starszy brat - wojewoda wileński i hetman wielki litewski Kazimierz Jan). Niedawno przebadano postawy sejmików mazowieckich wobec działalności fakcji sapieżyńskiej w „powiedeńskim” okresie panowania

\footnotetext{
„Ostatni wolności naszej klejnot”. Sejm Rzeczypospolitej za panowania Jana III Sobieskiego, Poznań 2014, s. 645, 663.

${ }^{32}$ AGAD, APP, sygn. 163a, t. 8, s. 333-334, K. Szczuka do S.A. Szczuki, Warszawa, 18 XII 1682.

33 Z. Hundert, Marszalek wielki koronny Stanisław Herakliusz Lubomirski wobec sejmu 1683 roku i problemu wojny z Porta Osmańska, „Saeculum Christianum” 2018, t. 25, s. 229 - tam również odniesienie do listu Krasińskiego do Szczuki - ale z błędami we wskazaniu datacji (8 IX, a nie 8 XII 1688) i okoliczności (generał deputacki, a nie sejmik ziemi warszawskiej).

${ }^{34}$ R. Kołodziej, ,, Ostatni wolności naszej klejnot”..., s. 551.

${ }^{35}$ Ostatnio na ten temat: J. Stolicki, Konflikt Jana III z opozycją.., s. 66-72; R. Kołodziej, Stronnictwo Sapiehów..., s. 110-113 - tam odniesienia do dalszej literatury.

${ }^{36}$ K. Wiśniewski, Urzą marszatkowski koronny w bezkrólewiach XVII-XVIII wieku (16321736), Warszawa 2015, s. 321; Z. Hundert, Marszałek wielki koronny..., s. 229.
} 
Jana III i wykazano, że uznawana powszechnie za regalistyczną szlachta mazowiecka na ogół nie występowała przeciw Sapiehom w sposób stanowczy. Mogło to być skutkiem działalności klienteli sapieżyńskiej na Mazowszu, choć nie dysponowano wtedy na to jeszcze dowodami ${ }^{37}$. Teraz można podeprzeć się słowami Krasińskiego, że B.P. Sapieha ingerował choćby w sejmik warszawski - ale nie tylko. W 1695 r. ówczesny wierny wykonawca dyspozycji politycznych dworu, podkomorzy koronny i starosta czerski Kazimierz Ludwik Bieliński, zwrócił uwagę, że osoby, które mogą zerwać sejmik czerski, pozostają w związkach z litewskim podskarbim ${ }^{38}$. Widać zatem, że opozycja sapieżyńska, podobnie jak dwór, również na Mazowszu utrzymywała swoje struktury - a te struktury mogły ingerować m.in. w wybór deputatów do Trybunału Koronnego.

Analizując zebrany materiał dotyczący wyboru deputatów do Trybunału z województwa mazowieckiego w 1688 r., należy stwierdzić, że dwór stworzył nieformalne struktury, poprzez które oddziaływał nie tylko na przebieg sejmiku deputackiego, ale także na sejmiki partykularne. Dostrzec tu można również aktywność opozycji, choć jej struktury „terenowe” nie zostały szerzej rozpoznane, dowiedziono tylko, że takowe istniały. Z powyższego wywodu wynika, że dwór królewski, budując swoje zaplecze polityczne w województwie mazowieckim, opierał się przede wszystkim na osobach, których hierarchię ważności wyznaczały ich faktyczne możliwości działania, a nie pozycja wynikająca z urzędu. W ogóle niedostrzegalna jest aktywność wojewody mazowieckiego i starosty płockiego Wojciecha Krasińskiego, który wtedy wycofał się chyba z życia publicznego - albo został z niego wyrugowany. Przykładowo, w czasach panowania Jana III obecny był tylko na jednym sejmie (w 1677 r,), mimo że swój urząd sprawował do śmierci w $1691 \mathrm{r} .{ }^{39} \mathrm{~W}$ miejscowych układach w $1688 \mathrm{r}$. nie widać też obecności drugiego co do ważności urzędnika województwa - i jedynego w nim kasztelana większego (krzesłowego), tj. kasztelana czerskiego. W tym jednak przypadku proces wykorzystania tej godności do usług partii dworskiej został już zainicjowany, z tym że w 1688 r. jeszcze nie procentował. Od 1687 r. kasztelanem czerskim był Stanisław Morsztyn, wieloletni oberszter zaciągu niemieckiego - a od 1674 r. dowódca komputowej gwardii pieszej królowej Marii Kazimiery. Zaliczał się on zresztą do protegowanych króla oraz królowej - samo zaś wprowadzenie go do elity senatorskiej województwa mazowieckiego było zgodne z logiką Jana III, chcącego do kręgów władzy (lokalnych i centralnych) wprowadzać zaufanych podkomendnych z wojska

${ }^{37}$ Z. Hundert, Działalność Sapiehów w ,powiedeńskim” okresie panowania Jana III (16831696) w świetle akt sejmikowych województwa mazowieckiego [w:] T. Ciesielski, M. Sawicki (red.), Wielkie rody dawnej Rzeczypospolitej..., s. 87-104.

38 Наиылянальны гістарычны архіў Беларусі, Мінск [dalej: NHAB], f. 695, op. 1, sygn. 60, k. 81-81v, K.L. Bieliński do Jana III, Czersk, 27 V 1695.

${ }^{39}$ R. Kołodziej, ,, Ostatni wolności naszej klejnot”..., s. 657. 
koronnego ${ }^{40}$. Morsztyn związał się zresztą z Mazowszem, toteż nie zabrakło mu ambicji i w 1696 r. - po śmierci wojewody mazowieckiego F. Wessla - zapragnął objąć jego urząd, lecz otrzymał go dopiero od Augusta II ${ }^{41}$.

Koordynatorem, ale i inspiratorem działań partii dworskiej w województwie mazowieckim był niewątpliwie S.A. Szczuka, którego w tych poczynaniach wspierał, a czasem zastępował, krewny - K. Szczuka. Opat paradyski był osobą świetnie zorientowaną w lokalnym życiu publicznym oraz w lokalnych układach, co wyraźnie wynika z jego korespondencji. Szczukowie, wykorzystując swoją bliską pozycję przy władcy, stworzyli własny układ klientalny w postaci informatorów i szlachty aktywnej sejmikowo (w tym nawet szczebla senatorskiego, jak F. Drozdowski). Potrafili też pozyskiwać do współpracy kluczowe w regionie postacie, począwszy od J.D. Krasińskiego, którego praca przy organizacji sejmików w Warszawie generału tudzież partykularnego zjazdu ziemi warszawskiej - przyczyniła się do zdobycia upragnionego urzędu senatorskiego w sąsiednim, ale blisko związanym z mazowieckim, województwie płockim. Krasiński był gotów stanąć do konfrontacji z Lubomirskim i Sapiehami, ale jego motywacja nie była chyba zbyt głęboka. Z badań Krzysztofa Wiśniewskiego wynika, że Krasiński, jako starosta warszawski, wielokrotnie - zwłaszcza w okresach bezkrólewia (1668/1669, 1673/1674 i 1696/1697) - wchodził w spory kompetencyjne z urzędem marszałkowskim, bez znaczenia, czy na jego czele stał Jan Sobieski, czy potem S.H. Lubomirski ${ }^{42}$. Gdy dwór królewski przebywał w Warszawie, zaczynała obowiązywać władza urzędu marszałkowskiego, która minimalizowała kompetencje starosty warszawskiego, z czym Krasiński wyraźnie się nie godził. Jego uprawnienia sądowo-policyjne wracały, jeśli dwór nie rezydował w Warszawie - a urząd marszałkowski, bez względu na to, czy był przy nim któryś z marszałków, funkcjonował stale w miejscu przebywania króla. W czasie odbywania tytułowego generału deputackiego monarcha ze swoją świtą znajdował się na Rusi, tym sposobem Krasiński, jako nadzorujący generał deputacki, mógł korzystać nie tylko ze swych nieformalnych atrybutów (jak liczne znajomości), ale także z uprawnień starosty grodowego. Nie dziwi więc, że Szczuka angażował go do działań na rzecz dworu w walce z opozycją.

W powyższym szkicu nakreślono linię podziału stronnictw w województwie mazowieckim w 1688 r., która w dość dużym stopniu pokrywała się z polaryzacją sceny politycznej na szczeblu centralnym. Nie wszystkie kwestie związane z mazo-

40 Z. Hundert, Poselstwo od wojska koronnego..., s. 42-43, 50-52.

${ }^{41}$ NHAB, f. 695, op. 1, sygn. 60, k. 127, S. Morsztyn do Jana III, w Chorzelowie, 14 III 1696. O S. Morsztynie zob. A. Link-Lenczowski, Morsztyn (Morstin) Stanisław [w:] PSB, t. 21, 1976, s. $822-826$.

${ }^{42}$ K. Wiśniewski, Urząd marszatkowski koronny..., s. 80-82, 84, 116-117, 234-235. 
wieckim klientalizmem i jego specyfiką mogły zostać tu poruszone ${ }^{43}$, w tym te dotyczące samego oddziaływania patronów na prace Trybunału w kadencji 1688/1689 przez swych mazowieckich protegowanych (tu problemem jest brak dokumentów prac samego Trybunału). Mam jednak nadzieję, że wywód ten zachęci do dalszej dyskusji nad lokalnymi układami politycznymi w dobie panowania Jana III ${ }^{44}$, w tym tytułowymi mazowieckimi, jak również zainspiruje do kolejnych badań nad pozasystemowymi mechanizmami obsadzania funkcji deputatów trybunalskich.

\title{
THE MECHANISM OF ELECTING DEPUTIES \\ TO THE CROWN TRIBUNAL FROM THE MAZOVIA PROVINCE IN 1688. A CONTRIBUTION TO THE RESEARCH INTO CLIENTELISTIC RELATIONS IN MAZOVIA DURING THE REIGN OF JOHN III SOBIESKI
}

\begin{abstract}
The article presents the mechanism of electing deputies to the Crown Tribunal from the Mazovia Province in 1688. Moreover, it attests to its connections to the local political power groups which were created by both supporters and opponents of the court of John III Sobieski. The paper also serves as a contribution to further research into local political power groups during the reign of Sobieski, especially in the Mazovia region.

Keyw ords: clientelism, John III Sobieski, Mazovia

${ }^{43}$ Pewne uwagi o specyfice mazowieckiego klientalizmu zob. np. J. Urwanowicz, Polityczna aktywność szlachty mazowieckiej w latach 1669-1793 [w:] Dzieje Mazowsza, t. 2: Lata 1527-1794, red. J. Tyszkiewicz, Pułtusk 2015, s. 592-596.

${ }^{44}$ O protekcji patrona przy obejmowaniu funkcji wybieralnych na sejmikach w tym okresie pisał np. Jan Jerzy Sowa: , Upewniam Waszmość Pana i Dobrodzieja, że mnie Waszmość Pan będziesz miat za jednego esklawa sobie": Relacje patron - klient w Koronie końca XVII w. w świetle listów braci Wojakowskich do Adama Mikołaja Sieniawskiego [w:] P. Borek, M. Olma (red.), Epistolografia staropolska, t. 6, Kraków 2015, s. 179-210.
\end{abstract}

